\title{
Field performance of Pinus ponderosa seedlings inoculated with ectomycorrhizal fungi planted in steppe-grasslands of Andean Patagonia, Argentina
}

\author{
Comportamiento a campo de Pinus ponderosa inoculado con hongos ectomicorrícicos \\ plantado en pastizales de estepa en Patagonia Andina, Argentina
}

\author{
Carolina Barroetaveña a,b,c*, Vilma Noemí Bassani a, Juan Ignacio Monges a , Mario Rajchenberg a,b,c \\ ${ }^{a}$ Centro de Investigación y Extensión Forestal Andino Patagónico (CIEFAP), Esquel, Chubut, Argentina. \\ ${ }^{\mathrm{b}}$ Consejo Nacional de Ciencia y Tecnología (CONICET), Argentina.

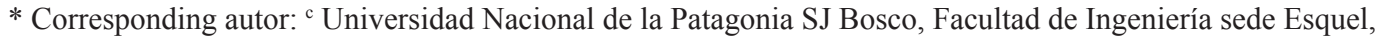 \\ Centro Forestal CIEFAP, C.C. 14, 9200, Esquel, Chubut, Argentina, cbarroetavena@ciefap.org.ar
}

\begin{abstract}
SUMMARY
Pinus ponderosa is the most planted tree species in the ecotone area of Patagonia, Argentina, subjected to water stress and a Mediterranean climate. Ectomycorrhizal (EM) fungi form obligate mutually beneficial associations with ponderosa pine which improve plant growth and resistance to adverse conditions. This work reports field results of a five-year trial aimed at determining which EM fungal species were most beneficial for pine seedling survival, growth and nutritional status after plantation. The study was conducted in two experimental plantations located in Patagonian grasslands, where ponderosa pine seedlings inoculated with Suillus luteus, Rhizopogon roseolus, Hebeloma mesophaeum and pine duff plus a control were planted in a randomized block design. Inoculation with $R$. roseolus and $S$. luteus significantly improved ponderosa pine growth following outplanting in the site subjected to higher water stress, compared with inoculations with $H$. mesophaeum and pine duff. Pine duff was characterized by abundant Amphinema byssoides morphotypes. These results allow recommending appropriate EM species for afforestation in vast areas of Patagonia, and confirm that different EM species behave differently after transplant, generating different plant growth that may not be detected at nursery stage. Inoculation with these growths promoting edible mycorrhizal species could provide better tree growth and a non-timber product while stands are growing.
\end{abstract}

Key words: Rhizopogon roseolus, Suillus luteus, Hebeloma mesophaeum, Amphinema byssoides, wild edible fungi.

\section{RESUMEN}

Pinus ponderosa es la especie forestal más plantada en el área de ecotono de Patagonia, Argentina, sujeta a estrés hídrico y clima mediterráneo. Los hongos ectomicorrícicos forman asociaciones obligadas y mutuamente beneficiosas con $P$. ponderosa, que mejoran el crecimiento de las plantas y la resistencia a condiciones adversas. Este trabajo reporta resultados de un ensayo de campo de cinco años de duración, que buscó determinar cuáles especies ectomicorrícicas son más beneficiosas para la supervivencia, el crecimiento, y el estatus nutricional de P. ponderosa luego de la plantación. El estudio se condujo en dos plantaciones experimentales en pastizales patagónicos, donde plántulas de P. ponderosa inoculadas con Suillus luteus, Rhizopogon roseolus, Hebeloma mesophaeum y hojarasca de $P$. ponderosa junto a un control sin inoculación fueron plantados en un diseño de bloques al azar. La inoculación con $R$. roseolus y $S$. luteus mejoró significativamente el crecimiento de $P$. ponderosa luego del trasplante en el sitio con mayor estrés hídrico, en comparación con los tratamientos inoculados con H. mesophaeum u hojarasca. El tratamiento con hojarasca mostró abundante colonización de Amphinema byssoides. Estos resultados permiten recomendar especies ectomicorrícicas apropiadas para vastas áreas de forestación en Patagonia, y confirmar que diferentes especies ectomicorrícicas se comportan distinto en los sitios de plantación, generando crecimientos diferentes que pueden no ser detectados en la fase de vivero. La inoculación con especies de hongos promotores de crecimiento que producen fructificaciones comestibles ofrece mejores crecimientos a las plantas, junto a un producto forestal no maderero aprovechable mientras la forestación crece.

Palabras clave: Rhizopogon roseoulus, Suillus luteus, Hebeloma mesophaeum, Amphinema byssoides, hongos comestibles.

\section{INTRODUCTION}

Ponderosa pine (Pinus ponderosa Dougl. ex Laws.) is the most commonly planted tree species in the forest-steppe ecotone located on the eastern slope of the Andes in Patagonia, Argentina (CFI-FUNDFAEP 2009). This ecotone com- prises a narrow $(80 \mathrm{~km})$ and long $(\sim 1,500 \mathrm{~km})$ strip that harbors most of the sites suitable for afforestation in the region. However, the challenging climate conditions with frequent water stress and high summer temperatures demand resistant seedlings in order to ensure plantation success. As in any environmentally harsh scenario, mycorrhizas may play 
a decisive role in seedling performance in this area of Patagonia (Querejeta et al. 1998, Parladé et al. 2004).

It is well known that ectomycorrhizas improve conifer seedling survival and growth rates by increasing the uptake and transfer of nutrients and water to the host plant, particularly in habitats exposed to water stress (Smith and Read 1997). In Patagonia, these water-limited areas present a typical vesicular-arbuscular symbiota with native grasses and shrubs, without ectomycorrhizal fungal species suitable to colonize Pinaceae (Godoy et al. 1994).

Ectomycorrhizal inoculation experiments of Pinus species have been widely carried out around the world (Castellano 1996). In some cases, these experiments have used ponderosa pine seedlings, and positive effects of inoculation on outplanting success have been reported, with increasing survival and growth of inoculated seedlings (Castellano 1996, Steifeld et al. 2003). There are, however, few records of inoculation experiments and selection of ectomycorrhizal species for Pinus spp. in Patagonia. Studies by Peredo et al. (1992), Martínez et al. (2007), and Barroetaveña et al. (2012) on ponderosa pine are the only precedents for this kind of studies in the region.

The use of spores as a source of ectomycorrhizal inoculum has been proved to be efficient, accessible and of low cost (Rincón et al. 2007, Parladé et al. 2004, Steinfeld et al. 2003). It is necessary to select those fungi with abundant and widespread fruiting bodies with high spore numbers (Barroetaveña et al. 2005 and 2012, Bassani et al. 2012). A previous work monitoring the effectiveness of ponderosa pine ectomycorrhizal spore inoculation at the nursery stage showed that Suillus luteus (L.) Roussel (Suillaceae, Boletales, Basidiomycota) and Rhizopogon roseolus (Corda) Th. Fr. (Rhizopogonaceae, Boletales, Basidiomycota), followed by Hebeloma mesophaeum (Pers.) Quél. (Strophariaceae, Agaricales, Basidiomycota) achieved the highest mycorrhization percentages, although with no significant effects on plant growth parameters (Barroetaveña et al. 2012). Nevertheless, the positive effect of these species on seedlings survival and growth should be tested in plantation sites; hence, we hypothesize that different ectomycorrhizal species will promote different host survival and growth under different field conditions.

This work reports field results of a five-year trial aimed at assessing the benefits of ectomycorrhizal fungi inoculated to ponderosa pine seedlings that were planted in two ecotonal areas of Patagonia (Argentina) showing contrasting environmental and soil conditions. The objective is to determine which ectomycorrhizal fungal species were the most beneficial for pine seedling survival, growth, and nutritional status on each site five years after plantation.

\section{METHODS}

Study sites. Two experimental plantations (in areas excluded to livestock) were established in May 2005 in two different locations in the west of Chubut province, Argentina.
Both sites are grasslands dominated by herbs (Stipa sp., Acaena spp., Senecio spp.) and shrubs (Mulinum spinosum Pers.) and belong to the Occidental floristic District, with precipitations concentrated mainly in winter $(46 \%)$ and fall $(27 \%)$. These sites were: (a) Vargas field site $\left(42^{\circ} 55^{\prime}\right.$ $21^{\prime \prime} \mathrm{S}$ and $71^{\circ} 14^{\prime} 41.3$ " $\mathrm{W}$, located in the surroundings of Esquel, Chubut). This site presents an elevation of $797 \mathrm{~m}$ a.s.l., $3^{\circ}$ slope, $70^{\circ} \mathrm{NE}$ aspect, and a mean annual precipitation of $450 \mathrm{~mm}$. Soil is a sandy loam, with a $\mathrm{pH}$ of 6.70 $\left(\mathrm{H}_{2} \mathrm{O}\right)$, low organic matter content and a Fieldes negative reaction to allophanes (Fieldes and Perrot 1966). The other (b) Leleque field site $\left(42^{\circ} 21^{\prime} 07.3^{\prime \prime} \mathrm{S}\right.$ and $71^{\circ} 10^{\prime} 27^{\prime \prime} \mathrm{W}$, located in the surroundings of Leleque, Chubut), at $748 \mathrm{~m}$ a.s.l. on a flat plateau, and receives a mean annual precipitation of $580 \mathrm{~mm}$. Soil is a sandy loam, with a $\mathrm{pH}$ of 6.47 $\left(\mathrm{H}_{2} \mathrm{O}\right)$, high organic matter content and Fieldes positive reaction to allophanes that determines high water retention.

Seedlings production and inoculation. Experiment design. Ponderosa pine seedlings used in this study were grown at the forest nursery, Universidad Nacional de la Patagonia SJ Bosco, located in Esquel ( $42^{\circ} 54^{\prime} 35^{\prime \prime} \mathrm{S}$ and $\left.71^{\circ} 18^{\prime} 38^{\prime \prime} \mathrm{W}\right)$, Argentina. Ten-month-old containerized ponderosa pine seedlings, grown in $50 \%$ peat $+50 \%$ volcanic sand, and fertirrigated with nitrogen, phosphorus and potassium according to nursery protocols, were transplanted to $550 \mathrm{~cm}^{3}$ plastic pots, adding a 2:1 mixture of steam tyndallized topsoil and sterilized volcanic sand, as described in Barroetaveña et al. (2012). Four treatments were set up using spore suspensions of Suillus luteus, Rhizopogon roseolus (applied with a dose of $6 \times 10^{7}$ spores per plant) and Hebeloma mesophaeum (applied with a dose of $2 \times 10^{7}$ spores per plant) and pine duff (taken from five points at a neighboring ponderosa pine plantation between $2-3 \mathrm{~cm}$ from the surface down to the mineral soil). Pine duff, included as a treatment in order to detect whether other species present in plantations are effective ectomycorrhizal colonizers at early stages of seedlings establishment, was homogenized, triturated and added to the top-soil of each pot $(3 \mathrm{~cm}$ thick layer) within a week of being collected. A non-inoculated control was also included to check for contaminations and to compare seedling growth. Seedlings were kept nine months in a greenhouse and watered only with water from a well.

Nine months later and before planting, 10 randomly selected seedlings were measured and mycorrhization percentages assessed, as indicated in Barroetaveña et al. (2012). Suillus luteus and R. roseolus were the most effective colonizers ( 38.4 and $35 \%$, respectively), while H. mesophaeum presented $11.4 \%$ of mycorrhization. No significant differences in collar diameter and shoot height were detected. In all treatments and control, except $H$. mesophaeum, we detected adventitious colonization by Cenococcum sp., while the assays with $H$. mesophaeum and $R$. roseolus presented E-strain, always with less than $5 \%$ colonization (Barroetaveña et al. 2012). Pine duff treatment had $30.4 \%$ colonization with a mix of Ceno- 
coccum sp. Rhizopogon sp. and E-strain morphotypes. Seedlings were then outplanted in both field sites using a randomized block design with five blocks (being the lines) and four inoculation treatments plus a non-inoculated control. The plantation framework was set at $3 \times 3 \mathrm{~m}$, with 20 seedlings per experimental unit (treatment by block), each one protected with a metallic mesh to prevent rodent attack. Stem height and collar diameter of each seedling/ treatment were measured previous to planting, to confirm sampling values.

Survival and growth measurements. Soil and foliar analyses. During the first three years after plantation, data on survival and stem growth were taken annually in March and, at the third year, collar diameter was also measured. On the fifth year, total height, collar diameter and mycorrhization status were assessed.

Foliar nutrient content was evaluated at year four (February 2009) for Vargas site only, where treatment effects on growth were detected. Analyses were conducted on composite samples of five plants by experimental unit, by taking only last year leaves, using plastic gloves and keeping samples in paper envelopes until taken to the laboratory. Afterwards they were washed with distilled water, oven-dried at $70{ }^{\circ} \mathrm{C}$ for $24 \mathrm{~h}$ and grinded to pass through a $1 \mathrm{~mm}$ sieve. Total nitrogen was determined by semi-micro Kjeldahl; total phosphorus, calcium, magnesium, and potassium by dry digestion at $550{ }^{\circ} \mathrm{C}$; and $\mathrm{HCl}$ extraction (Richards 1993) followed by colorimetric (phosphorus) and flame emission spectrometric atomic absorption (calcium, magnesium, and potassium) determinations.

To further analyze soil properties, composite soil samples were taken from each site to evaluate soil texture by sedimentation (calgon treated sample without digestion of organic matter), $\mathrm{pH}$ in 1:1 dilution of soil in water, $\mathrm{pH}$ in FNa 2' and pH FNa 60' (Fieldes and Perrot 1966), soil organic matter percentage using loss on ignition, available phosphorous, $\mathrm{S}_{-} \mathrm{SO}_{4}$ and total nitrogen percentage using the Kjeldahl method.

Mycorrhizal evaluation and morphotype classification. In the fifth year, four seedlings per treatment at each plantation were randomly selected to dig up lateral roots to obtain at least $1 \mathrm{~m}$ of fine roots (and up to $2.30 \mathrm{~m}$ ). Samples were stored in plastic bags at $4{ }^{\circ} \mathrm{C}$ and analyzed within a week. Mycorrhizal morphotypes were classified using a dissecting microscope (Wild M3Z) with 10-40x magnification, and a compound microscope (Zeiss-Axioscop), focusing on distinctive features easily recognizable, according to Barroetaveña and Rajchenberg (2003), Agerer and Rambold (2010) and Barroetaveña et al. (2010, 2012). The relative frequency of each ectomycorrhizal type on each plant was calculated as the proportion of root tips assigned to each morphotype with the total number of ectomycorrhizal tips. These data were then averaged to produce a mean relative frequency for each ectomycorrhizal type in each treatment. Concise morphological descriptions were made for morphotypes different from those of the inoculated species, already described in Barroetaveña et al. (2012), and are presented in annex 1.

Data analyses. The analyses of annual increments during the first three years along with the inoculation treatment effects were performed with repeated ANOVA measures (time being the repeated measured factor) with a $P \leq 0.05$ significance level, using SPSS for Windows v. 17.0. The assumptions of sphericity and equal variance-covariance matrices were confirmed with Mauchly and Levene tests, respectively. Annual increment data were considered in the analyses only when no evidence of hare (Lepus europaeus Pallas) browsing was present. Differences in stem height, collar diameter, cumulative growth at the third year, mycorrhization percentages and total height after five years of plantation were detected with one way ANOVA and Tukey's test for multiple comparisons. Normality and homoscedasticity of variances were confirmed using the Shapiro-Wilk method and Levene's test. Differences in foliar nutrient contents among treatments were analyzed separately for each nutrient with one-way ANOVA and Tukey's test as previously detailed. Mycorrhizal colonization at the fifth year was analyzed separately for each morphotype with one-way ANOVA and Tukey's test. In all cases, when the normality and/or homoscedasticity assumptions were not met, data transformations were tested and, as a last resource, nonparametric analyses were performed (Friedman test). Seedlings survival was evaluated at the third year, considered in percentages as number of dead seedlings/20x100 per experimental unit, using Friedman test. All analyses were performed with a significance level of $P \leq 0.05$, using INFOSTAT (Di Rienzo 2011).

\section{RESULTS}

At the time of field outplanting, no differences among treatments in seedlings height(ANOVA, $P=0.63$; mean 9.67 $\mathrm{cm}$ ) or collar diameter (ANOVA, $P=0.53$; mean $4.76 \mathrm{~mm}$ ) were detected. Soil chemical and physical properties evidenced some differences between field sites (Table 1). Although the $\mathrm{pH}$ was close to neutral and textural compositions were similar, Leleque site showed the presence of amorphous aluminosilicates (allophanized clays) ( $\mathrm{pH} \mathrm{FNa}$ $>9.2$,) and higher organic matter and nitrogen content than those present in Vargas site. On the other hand, phosphorus and sulphur contents were higher in Vargas site.

Vargas plantation. Growth increment and survival between years 1-3. Annual stem growth showed significant differences among inoculation treatments (tests of between-subjects effects, $P=0.008), R$. roseolus treatment being significantly higher than pine duff and $H$. mesophaeum treatments (Tukey test $P=0.017$ and $P=0.039$, respectively). Effect of year was also significant (tests of 
Table 1. Soil physical and chemical properties from Leleque and Vargas field sites.

Propiedades físicas y químicas del suelo de los sitios de plantación Leleque y Vargas.

\begin{tabular}{|c|c|c|}
\hline & Vargas & Leleque \\
\hline pH water $1: 1$ & 6.79 & 6.47 \\
\hline pH FNa 2' (a) & 8.16 & 9.64 \\
\hline pH FNa 60’ (b) & 8.12 & 9.73 \\
\hline$\% \mathrm{OM}^{(\mathrm{c})}$ & 2.36 & 5.09 \\
\hline Clay \% & 5 & 1 \\
\hline Silt \% & 15 & 17 \\
\hline Sand \% & 79 & 82 \\
\hline Textural class ${ }^{(d)}$ & Sandy loam & Sandy loam \\
\hline $\mathrm{N} \%$ & 0.106 & 0.210 \\
\hline $\mathrm{P}(\mathrm{mg} / \mathrm{kg})$ & 31 & 13 \\
\hline $\mathrm{S}-\mathrm{SO}_{4}^{-}(\mathrm{mg} / \mathrm{kg})$ & 93 & 73 \\
\hline
\end{tabular}

(a) y (b) Fieldes and Perrot (1966).

(c) Davies (1974) method, for dry combustion.

(d) Bouyoucos (1962) Method, by sedimentation (calgon treated sample without digestion of organic matter).

within-subjects effects, $P<0.0001$ ), with significantly higher mean annual growth the third $(21.07 \mathrm{~cm})$ and second year $(10.20 \mathrm{~cm})$, as compared to the first year $(5.77$ $\mathrm{cm})$. Pairwise comparison of treatment effect by year showed that there were no significant differences among treatments the first year, but in the second and third year $R$. roseolus treatment showed significantly higher values than pine duff and H. mesophaeum treatments (figure 1A).

Cumulative growth at the third year showed highly significant differences among treatments (ANOVA, $P=0.005$ ). Rhizopogon roseolus inoculated seedlings $(43.8 \mathrm{~cm}$; $95 \%$ confidence interval $39.3-48.2 \mathrm{~cm}$ ) showed significantly higher increments than those showed by pine duff $(32.5 \mathrm{~cm} ; 95 \%$ confidence interval $28.0-36.9 \mathrm{~cm}$. Tukey test, $P=0.012)$ and $H$. mesophaeum $(33.0 \mathrm{~cm} ; 95 \%$ confidence interval $28.6-37.5 \mathrm{~cm}$. Tukey test, $P=0.017$ ) treatments, followed by S. luteus treatment ( $40.6 \mathrm{~cm} 95 \%$ confidence interval $36.2-45.1 \mathrm{~cm})$. The control presented an intermediate value $(35.2 \mathrm{~cm}$; $95 \%$ confidence interval 30.8-39.7 cm). Collar diameter at the third year showed the same trend (one way ANOVA, $P=0,0001$ ), with $R$. roseolus $(2.06 \mathrm{~cm}$; $95 \%$ confidence interval $1.96-2.17 \mathrm{~cm})$ and $S$. luteus $2.07 \mathrm{~cm}$; $95 \%$ confidence interval 1.96-2.17 $\mathrm{cm})$ treatments significantly higher than $H$. mesophaeum $(1.74 \mathrm{~cm} ; 95 \%$ confidence interval $1.63-1.84 \mathrm{~cm})$, pine duff $(1.73 \mathrm{~cm} ; 95 \%$ confidence interval $1.63-1.83 \mathrm{~cm})$ and control $(1.82 \mathrm{~cm} ; 95 \%$ confidence interval $1.71-1.91 \mathrm{~cm})$.

Plant survival was not evaluated in this site because the plantation suffered an attack by the rodent Ctenomys magellanicus Bennett (tucu-tucu), a mammal that forms below-soil colonies and feeds on roots, causing patches of plant mortality. It was not possible to clearly establish which missing or dead seedlings were caused by tucu-tucu attacks or by physiological stress.

Vargas plantation. Comparison of growth parameters, mycorrhizal colonization and nutrient foliar contents among ectomycorrhizal inoculation treatments after five years. Stem height significantly differed between treatments (ANOVA, $P<0.001$ ), with $R$. roseolus showing significantly higher values than those presented by $H$. mesophaeum, pine duff and control (Tukey test, $P<0.05$ ), followed by $S$. luteus inoculated plants. Collar diameter also showed significant differences among treatments (ANOVA, $P=0.008$ ) with $R$. roseolus being significantly higher than the other treatments (Tukey test, $P<0.05$ ), followed by $S$. luteus (table 2).

Foliar analyses showed that nutrients contents did not significantly vary between treatments and control, phosphorus (ANOVA, $P=0.407$ ), nitrogen (ANOVA, $P=0.673$ ), potassium (ANOVA, $P=0.181$ ), magnesium (ANOVA, $P=0.649$ ) and calcium (Friedman test, $P=0.63$ ). Mean values for each nutrient are presented in table 3 .

Total mycorrhizal colonization varied depending whether senescent tips were considered in the analyses or not, as they were abundant across treatments (table 4). In both cases, differences among treatments were not statistically significant, with values ranging from $36-54.7 \%$ of mycorrhization when only fresh root tips were considered (table 2). Plants from the H. mesophaeum, R. rosoelus and $S$. luteus treatments presented higher proportion of colonized tips with the inoculated species (table 4). Regarding contamination, E-strain-fungi and Cenococcum sp. were the most widespread, although scarce spontaneous colonizers, already present in seedlings at the moment of outplanting. Suillus luteus and $R$. roseolus were adventitious in the control and H. mesophaeum treatments, respectively. Pine duff was the only treatment presenting the Amphinema byssoides morphotype, being the most abundant, followed by $S$. luteus and the E-strain morphotype (table 4).

Leleque plantation. Growth increment and survival between years 1-3. Annual stem growth showed no significant differences among inoculation treatments (tests of between-subjects effects, $P=0.694)$. Anyway, $R$. roseolus treatment showed, again, the higher growth, followed by pine duff and S. luteus treatments (figure 1B). The effect of the year was significant (tests of within-subjects effects, $P<0.0001$ ), with significantly higher mean annual growth for the third year $(16.30 \mathrm{~cm})$ as compared to the second $(10.60 \mathrm{~cm})$, and this also significantly higher than the first year $(5.99 \mathrm{~cm})$.

Cumulative growth at the third year showed no significant differences among treatments (ANOVA, $P=0.43$ ). However $R$. roseolus inoculated seedlings showed again the highest values $(35.5 \mathrm{~cm}$; $95 \%$ confidence interval 30.6- 

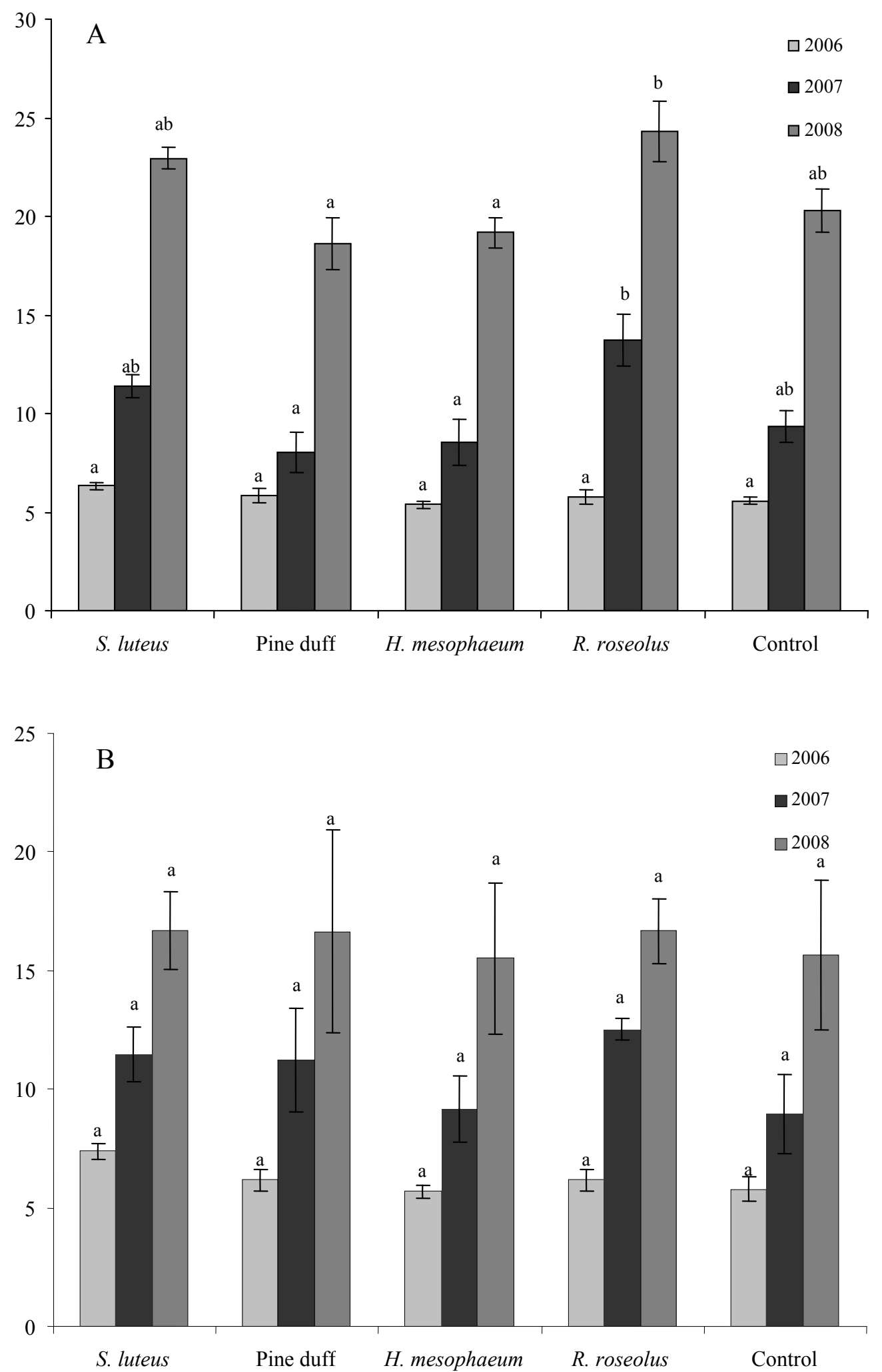

Figure 1. Relative annual stem growth from Vargas site (A) and Leleque field site (B) treatments. For each year, columns with a common letter are not significantly different according to multiple comparisons*, $P>0.05$.

Crecimiento anual relativo del vástago en los tratamientos del sitio Vargas (A) y del sitio Leleque (B). Para cada año, barras con una letra común no difieren significativamente según comparaciones múltiples *, $P>0,05$. 
Table 2. Ponderosa pine stem height, collar diameter and mycorrhization percentage of inoculated and non-inoculated (control) seedlings five years after field outplanting. For each field site and treatment, means in the same column followed by a common letter are not significantly different according to Tukey's test $P<0.05$.

Altura del vástago, diámetro del cuello y porcentaje de micorrización de plantas de Pinus ponderosa inoculadas y no inoculadas (control), cinco años después de la plantación. Para cada sitio de plantación y tratamiento, las medias en la misma columna seguidas por la misma letra no son significativamente diferentes según la prueba de Tukey, $P<0,05$.

\begin{tabular}{|c|c|c|c|c|}
\hline & Inoculation treatments & Stem height (cm) & Collar diameter $(\mathrm{cm})$ & Mycorrhization $\%{ }^{1}$ \\
\hline \multirow{5}{*}{ 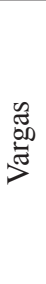 } & Rhizopogon roseolus & 107.52 a (2.59) & $3.73 \mathrm{a}(0.11)$ & $49.28 \mathrm{a}(16.65)$ \\
\hline & Suillus luteus & $97.74 \mathrm{ac}(2.15)$ & $3.43 \mathrm{ac}(0.10)$ & 54.71 a (9.03) \\
\hline & Hebeloma mesophaeum & $86.32 \mathrm{~b}(0.51)$ & $3.12 \mathrm{bc}(0.12)$ & $36.00 \mathrm{a}(11.07)$ \\
\hline & Pine duff & 88.03 bc (3.26) & 3.10 bc $(0.20)$ & 48.86 a (5.84) \\
\hline & Control & 89.84 bc (2.98) & $3.20 \mathrm{bc}(0.15)$ & $41.28 \mathrm{a}(14.21)$ \\
\hline \multirow{5}{*}{$\frac{\mathscr{0}}{\stackrel{\Xi}{0}}$} & Rhizopogon roseolus & 86.07 a (3.33) & $2.79 \mathrm{a}(0.11)$ & $53.17 \mathrm{ab}(4.57)$ \\
\hline & Suillus luteus & 85.17 a (1.67) & $2.98 \mathrm{a}(0.07)$ & $72.44 \mathrm{ab}(8.71)$ \\
\hline & Hebeloma mesophaeum & 78.65 a (3.78) & $2.67 \mathrm{a}(0.19)$ & $46.65 \mathrm{~b}(8.77)$ \\
\hline & Pine duff & 82.71 a (5.67) & $2.76 \mathrm{a}(0.28)$ & $69.75 \mathrm{ab}(4.31)$ \\
\hline & Control & 80.48 a (4.62) & $2.86 \mathrm{a}(0.20)$ & 80.78 a (6.29) \\
\hline
\end{tabular}

${ }^{1}$ Calculated as fresh ectomycorrhizal root tips*100 (total fresh root tips) ${ }^{-1}$; senescent ectomycorrhizal tips were not considered in this calculation. () Standard error.

Table 3. Nutrients content of ponderosa pine needles from each treatment in Vargas field site. For each treatment, means in the same column followed by a common letter are not significantly different according to Tukey's test $P<0.05$.

Contenido de nutrientes en acículas de Pinus ponderosa de cada tratamiento del sitio Vargas. Para cada tratamiento, medias en la misma columna seguidas de la misma letra no difieren significativamente según la prueba de Tukey, $P<0,05$.

\begin{tabular}{lccccc}
\hline \multirow{2}{*}{ Inoculation treatments } & \multicolumn{3}{c}{ Foliar nutrients } \\
\cline { 2 - 6 } & $\mathrm{P} \%$ & $\mathrm{Ca} \%$ & $\mathrm{Mg} \%$ & $\mathrm{~K} \%$ & $\mathrm{~N} \%$ \\
\hline R. roseolus & $0.12 \mathrm{a}(0.003)$ & $0.13 \mathrm{a}(0.006)$ & $0.16 \mathrm{a}(0.004)$ & $0.64 \mathrm{a}(0.027)$ & $1.35 \mathrm{a}(0.050)$ \\
S. luteus & $0.12 \mathrm{a}(0.005)$ & $0.14 \mathrm{a}(0.015)$ & $0.18 \mathrm{a}(0.010)$ & $0.71 \mathrm{a}(0.029)$ & $1.26 \mathrm{a}(0.048)$ \\
H. mesophaeum & $0.12 \mathrm{a}(0.005)$ & $0.14 \mathrm{a}(0.015)$ & $0.16 \mathrm{a}(0.007)$ & $0.70 \mathrm{a}(0.017)$ & $1.26 \mathrm{a}(0.045)$ \\
Pine duff & $0.11 \mathrm{a}(0.004)$ & $0.14 \mathrm{a}(0.008)$ & $0.17 \mathrm{a}(0.007)$ & $0.65 \mathrm{a}(0.020)$ & $1.29 \mathrm{a}(0.072)$ \\
Control & $0.12 \mathrm{a}(0.003)$ & $0.15 \mathrm{a}(0.009)$ & $0.16 \mathrm{a}(0.005)$ & $0.66 \mathrm{a}(0.024)$ & $1.26 \mathrm{a}(0.034)$ \\
\hline
\end{tabular}

() Standard error.

$40.5 \mathrm{~cm})$, followed by $S$. luteus $(34.2 \mathrm{~cm} ; 95 \%$ confidence interval 29.2-39.2 cm), pine duff $(33.0 \mathrm{~cm}$; $95 \%$ confidence interval 28.0-38.0 cm), H. mesophaeum $(31.0 \mathrm{~cm}$; $95 \%$ confidence interval 26.0-35.9 cm) and control (29.8 $\mathrm{cm} ; 95 \%$ confidence interval $24.8-34.8 \mathrm{~cm})$. Collar diameter at the third year did not show significant differences among treatments (one way ANOVA, $P=0.66$ ), with mean values ranging between $1.61-1.80 \mathrm{~cm}$.

Plant survival after three years (considering only live and dead plants, removing missing ones from the analyses) showed no significant differences among treatments (Friedman test $P=0.20$ ).
Leleque plantation. Comparison of growth parameters and mycorrhizal colonization among ectomycorrhizal inoculation treatments after five years. Stem height and collar diameter did not differ significantly among treatments (ANOVA, $P=0.734$ and $P=0.842$, respectively). Rhizopogon roseolus showed again higher values for both parameters, followed by S. luteus inoculated plants (table 2).

Total percentage of mycorrhizal colonization varied depending whether or not senescent tips were considered, as they were moderately abundant across treatments (table 5). When only fresh root tips were considered, percentage of mycorrhization varied significantly only between $H$. me- 
Table 4. Percentages of each kind of root tips of inoculated and non-inoculated (control) ponderosa pine seedlings, five years after field outplanting in Vargas site. For each kind of root tip, means in the same file followed by a common letter are not significantly different according to Friedman test, $P>0.05$.

Porcentajes de cada tipo de punta de raíz de plántulas de Pinus ponderosa inoculadas y no-inoculadas (control), cinco años después de la plantación en el sitio Vargas. Para cada tipo de punta de raíz, las medias en una misma fila seguidas de una letra común no difieren significativamente según la prueba de Friedman, $P>0,05$.

\begin{tabular}{lccccc}
\hline \multirow{2}{*}{ Root tips \% } & \multicolumn{5}{c}{ Treatments } \\
\cline { 2 - 6 } & H. mesophaeum & Pine duff & R. roseolus & S. luteus & control \\
\hline A. byssoides & $0.00 \mathrm{a}(0.00)$ & $10.86 \mathrm{~b}(3.68)$ & $0.00 \mathrm{a}(0.00)$ & $0.00 \mathrm{a}(0.00)$ & $0.00 \mathrm{a}(0.00)$ \\
S. luteus & $0.00 \mathrm{a}(0.00)$ & $4.48 \mathrm{a}(4.00)$ & $0.00 \mathrm{a}(0.00)$ & $21.86 \mathrm{~b}(5.80)$ & $19.82 \mathrm{a}(10.74)$ \\
H. mesophaeum & $4.08 \mathrm{a}(2.59)$ & $0.00 \mathrm{a}(0.00)$ & $0.00 \mathrm{a}(0.00)$ & $0.00 \mathrm{a}(0.00)$ & $0.00 \mathrm{a}(0.00)$ \\
R. roseolus & $9.14 \mathrm{a}(7.20)$ & $0.00 \mathrm{~b}(0.00)$ & $25.64 \mathrm{c}(12.05)$ & $0.00 \mathrm{~b}(0.00)$ & $0.00 \mathrm{~b}(0.00)$ \\
E-strain & $0.00 \mathrm{a}(0.00)$ & $0.36 \mathrm{a}(0.36)$ & $1.50 \mathrm{a}(1.50)$ & $0.70 \mathrm{a}(0.44)$ & $0.33 \mathrm{a}(0.33)$ \\
Cenoccocum & $0.91 \mathrm{a}(0.70)$ & $0.00 \mathrm{a}(0.00)$ & $1.64 \mathrm{a}(1.64)$ & $0.42 \mathrm{a}(0.42)$ & $0.65 \mathrm{a}(0.65)$ \\
Non-myco & $23.83 \mathrm{a}(5.83)$ & $14.69 \mathrm{a}(2.08)$ & $22.61 \mathrm{a}(4.95)$ & $18.47 \mathrm{a}(4.07)$ & $22.34 \mathrm{a}(3.69)$ \\
Senescent & $62.05 \mathrm{a}(6.56)$ & $69.61 \mathrm{a}(5.65)$ & $48.61 \mathrm{a}(9.45)$ & $58.55 \mathrm{a}(3.75)$ & $56.86 \mathrm{a}(7.15)$ \\
\hline
\end{tabular}

( ) Standard error.

Table 5. Percentages of mycorrhizal and non-mycorrhizal root tips of inoculated and non-inoculated (control) ponderosa pine seedlings, five years after field outplanting in Leleque site. For each kind of root tip, means in the same file followed by a common letter are not significantly different according to Friedman test $P>0.05$.

Porcentaje de cada tipo de punta de raíz de plántulas de Pinus ponderosa inoculadas y no-inoculadas (control), cinco años después de la plantación en el sitio Leleque. Para cada tipo de punta de raíz, las medias en una misma fila seguidas de una letra común no difieren significativamente según la prueba de Friedman, $P>0,05$.

\begin{tabular}{|c|c|c|c|c|c|}
\hline \multirow{2}{*}{ Root tips \% } & \multicolumn{5}{|c|}{ Treatments } \\
\hline & H. mesophaeum & Pine duff & R. roseolus & S. luteus & Control \\
\hline A. byssoides & $\begin{array}{l}0.00 \mathrm{a} \\
(0.00)\end{array}$ & $\begin{array}{l}35.67 \mathrm{~b} \\
(11.26)\end{array}$ & $\begin{array}{l}0.00 \mathrm{a} \\
(0.00)\end{array}$ & $\begin{array}{l}0.00 \mathrm{a} \\
(0.00)\end{array}$ & $\begin{array}{l}0.00 \mathrm{a} \\
(0.00)\end{array}$ \\
\hline S. luteus & $\begin{array}{l}19.38 \mathrm{a} \\
(11.87)\end{array}$ & $\begin{array}{l}3.43 \mathrm{a} \\
(3.43)\end{array}$ & $\begin{array}{l}0.00 \mathrm{a} \\
(0.00)\end{array}$ & $\begin{array}{c}60.05 \mathrm{~b} \\
(7.23)\end{array}$ & $\begin{array}{l}45.63 \mathrm{~b} \\
(16.48)\end{array}$ \\
\hline H.mesophaeum & $\begin{array}{c}11.29 \mathrm{a} \\
(7.27)\end{array}$ & $\begin{array}{l}0.00 \mathrm{a} \\
(0.00)\end{array}$ & $\begin{array}{l}0.00 \mathrm{a} \\
(0.00)\end{array}$ & $\begin{array}{l}0.00 \mathrm{a} \\
(0.00)\end{array}$ & $\begin{array}{l}5.77 \mathrm{a} \\
(5.77)\end{array}$ \\
\hline R. roseolus & $\begin{array}{l}0.00 \mathrm{a} \\
(0.00)\end{array}$ & $\begin{array}{l}0.00 \mathrm{a} \\
(0.00)\end{array}$ & $\begin{array}{c}24.66 \mathrm{~b} \\
(5.43)\end{array}$ & $\begin{array}{l}0.00 \mathrm{a} \\
(0.00)\end{array}$ & $\begin{array}{l}0.00 \mathrm{a} \\
(0.00)\end{array}$ \\
\hline E-strain & $\begin{array}{l}0.50 \mathrm{a} \\
(0.50)\end{array}$ & $\begin{array}{l}0.00 \mathrm{a} \\
(0.00)\end{array}$ & $\begin{array}{l}0.52 \mathrm{a} \\
(0.52)\end{array}$ & $\begin{array}{l}0.00 \mathrm{a} \\
(0.00)\end{array}$ & $\begin{array}{l}7.14 \mathrm{~b} \\
(3.29)\end{array}$ \\
\hline Cenoccocum & $\begin{array}{l}2.15 \mathrm{a} \\
(1.96)\end{array}$ & $\begin{array}{l}2.22 \mathrm{a} \\
(1.70)\end{array}$ & $\begin{array}{l}5.12 \mathrm{a} \\
(3.56)\end{array}$ & $\begin{array}{l}0.51 \mathrm{a} \\
(0.51)\end{array}$ & $\begin{array}{l}0.35 \mathrm{a} \\
(0.21)\end{array}$ \\
\hline Others & $\begin{array}{l}0.00 \mathrm{a} \\
(0.00)\end{array}$ & $\begin{array}{l}0.00 \mathrm{a} \\
(0.00)\end{array}$ & $\begin{array}{l}0.00 \mathrm{a} \\
(0.00)\end{array}$ & $\begin{array}{l}0.73 \mathrm{~b} \\
(0.73)\end{array}$ & $\begin{array}{l}0.47 \mathrm{~b} \\
(0.18)\end{array}$ \\
\hline Non-myco & $\begin{array}{l}40.87 \mathrm{a} \\
(10.77)\end{array}$ & $\begin{array}{c}16.59 \mathrm{a} \\
(0.91)\end{array}$ & $\begin{array}{c}24.68 \mathrm{a} \\
(4.24)\end{array}$ & $\begin{array}{c}25.94 \mathrm{a} \\
(9.66)\end{array}$ & $\begin{array}{c}12.90 \mathrm{a} \\
(3.44)\end{array}$ \\
\hline Senescent & $\begin{array}{c}25.82 \mathrm{a} \\
(9.11)\end{array}$ & $\begin{array}{c}42.08 \mathrm{a} \\
(7.33)\end{array}$ & $\begin{array}{l}45.02 \mathrm{a} \\
(12.08)\end{array}$ & $\begin{array}{l}12.76 \mathrm{a} \\
(10.05)\end{array}$ & $\begin{array}{c}27.74 \mathrm{a} \\
(6.39)\end{array}$ \\
\hline
\end{tabular}

( ) Standard error. 
sophaeum and the control (table 2). Plants from the H. mesophaeum, $R$. roseolus and $S$. luteus treatments presented the highest proportion of colonized root tips with the inoculated species (table 5).

E-strain and Cennococum were the most widespread, although always scarce, contaminant species, already present in seedlings at the moment of transplant. Suillus luteus heavily contaminated the $H$. mesophaeum treatment and the control, while $H$. mesophaeum appeared as contaminant only in the control. Also in this study site, pine duff treatment was the only one presenting Amphinema byssoides morphotypes, being the most abundant, followed by $S$. luteus and Cenoccocum (table 5).

Descriptions of E-strain, Amphinema byssoides and Cenococcum sp. morphypes are presented in annex 1 .

\section{DISCUSSION}

Our study showed that only Vargas site presented growth differences among inoculation treatments. The fact that this site presented lower precipitation values, along with less soil water retention capacity compared with Leleque site, suggests more extreme conditions for seedling establishment and higher dependency on mycorhiza (Smith and Read 1997). The higher $59.1 \%$ of senescent root tips from this site compared with $30.7 \%$ from Leleque strengthen the evidence that water stress was higher in Vargas site. Leleque site presented allophanized clays and higher organic matter content, both determining higher water retention capacity, along with higher $\mathrm{N}$ content, medium-high compared with reference values for the region (La Manna et al. 2011). On the other hand, $\mathrm{P}$ and $\mathrm{S}$ contents were lower in Leleque, $\mathrm{P}$ being low compared with reference values for the region (La Manna et al. 2011). This fact, however, could be associated with anion retention by allophanes (Wada 1985). Neither survival nor growth were significantly different among treatments at this site, probably because nutrients and water stress conditions were mild and may not allow the different ectomycorrhizal species express their potential. However, stem height and diameter mean values for all treatments were lower in Leleque plants compared with Vargas plants (table 2). This general trend could be attributable to lower temperatures in Leleque area, which is a valley that retains cold, although local meteorological records are not available. Lower soil Phosphorous content (twice as high at Vargas as at Leleque site) could have also contributed to this difference. Foliar nutrients concentrations for all treatments in this study were within the range of standard values for conifer needle tissues (Landis 1985). Comparing with values for outplanted $R$. roseolus inoculated plants reported by Steinfeld et al. (2003), nitrogen content was similar although phosphorus and potassium were lower in our plants, which is reasonable since these authors worked with containerized, recently transplanted seedlings (4 month old) in fertilized soils.
An interesting comparison of plant growth could be explored between Vargas site seedlings and those from a study performed by Davel et al. (2006) with bare-root seedlings in the same site. Using the mean annual increment (MAI), calculated as the final stem height minus stem height at transplant time, divided by the number of years since transplant, it could be observed that although Davel et al. (2006) worked with bare-root seedlings, presumably with higher transplant shock than that suffered by plants used in this study, MAI from their control plants (which lacked herbs removal as in our situation) was $13.67 \mathrm{~cm}$, $25.4 \%$ lower than that from the $R$. roseolus, and $6.5 \%$ lower than that from the $S$. luteus treatments of our study. Comparing with the other treatments and control, MAI was closer to that value, between 4 to $8 \%$ lower. But, when herbicide was applied to control plant competition, Davel et al. (2006) reported $21.17 \mathrm{~cm}$ of MAI, close to the $R$. roseolus treatment $(17.13 \mathrm{~cm})$ of this study. Although this comparison needs further validation, our results appear as promising for afforestation projects in Patagonia. The fact that similar growth-rates were achieved without herbicides or other weed control underlines the importance that appropriate mycorrhizal colonization has in seedling performance in this harsh environment. Stem height annual increments increased each year between 30 to $60 \%$ in both sites and treatments. This could probably be due to transplant shock attributable to water stress caused by poor root-soil contact, low permeability of suberized roots and a limited amount of roots in relation to shoots (Guarnaschelli et al. 2012). This occurs for some periods of time after outplanting. In time, seedlings establish new roots and the direct effects of transplanting stress is gradually reduced.

Regarding the fungal species, Rhizopogon roseolus is very abundant in Pinus spp. plantations established in Patagonia, Argentina (Barroetaveña et al. 2005), and offers many advantages compared to other ectomycorrhizal species. This is so because it allows good ectomycorrhizal root colonization in containerized seedlings under a fertiirrigation regime (Rincón et al. 2007), presenting numerous hyphae and rhizomorphs that penetrate the soil and maximize the capture of nutrients and moisture. This may provide seedlings with high tolerance to adverse environmental conditions, such as those present in Vargas site. In addition, $R$. roseolus can be easily inoculated in nurseries as spore suspensions, since it fruits abundantly and with high spore concentrations. Furthermore, its spores have a high germination rate, and a pronounced ability to colonize roots at low doses, maintaining their viability after storage at low temperatures (Martínez et al. 2007, Bassani et al. 2012). Numerous studies of conifer inoculation with Rhizopogon species have shown improvements in plantation establishment and development (Castellano 1996), some of them specifically with $R$. roseolus (Amaranthus and Malajczuk 2001, Parladé et al. 2004) and ponderosa pine seedlings (Steinfeld et al. 2003). Rhizopogon roseo- 
lus also produces edible sporocarps, with good attributes when they are young and fresh (Boa 2004), providing a non-timber product along the stand rotation cycle.

Suillus luteus also forms ectomycorrhizal associations exclusively with Pinaceae and is naturally distributed only in the northern hemisphere, where the natural distribution of these conifers occur (Dahlberg and Finlay 1999). However it has been extensively spread associated with Pinus spp. plantations in South American countries such as Ecuador, Chile, Argentina (Barroetaveña et al. 2005), and also in New Zealand. Many attempts to utilize Suillus spp. in large scale inoculation trials have been reported in different continents with good results (Dahlberg and Finlay 1999), as well as the improvement of the hosted seedlings performance and growth in the field (Querejeta et al. 1998, Rincón et al. 2007). Suillus spp. is an appreciated edible species (Boa 2004), widely exploited and harvested in Chile and Argentina (Fernández et al. 2012).

Amphinema byssoides is a corticioid fungus restricted to coniferous species, which is widely distributed in the northern hemisphere (Erland and Taylor1999). In Patagonia (Argentina) it has been extensively reported from ponderosa pine plantations of different ages and precipitation conditions, suggesting that it may be a successful competitor of other ectomycorrhizal fungi under Patagonian conditions (Barroetaveña et al. 2005), as is the case of Thelephora terrestris with pines in Western Australia (Dunstan et al. 1998). Amphinema byssoides is common in nutrientrich nursery soils as well as in mature boreal forests, indicating that it behaves as a multi-stage ectomycorrhizal fungus (Erland and Taylor 1999). In our study, root tips of this species were not present at the moment of plantation but, after five years, it was abundant only in the pine duff treatment, indicating that propagules came with duff, and no aerial contamination occurred. This way of colonization from soil inoculum has been previously reported (Erland and Taylor1999 and citations there included). Along with A. byssoides, duff treatment presented S. luteus, Cenoccocum spp. and E-strain morphotypes although in lower than half proportions than the first (cfr. tables 4 and 5).

Cenococcum geophilum Fr. is one of the most frequently encountered ectomycorrhizal fungi in nature. It has a cosmopolitan distribution, being frequent in temperate forests of the northern hemisphere, even under extreme conditions of anthropogenic impact (Flores et al. 1997). It has also been reported for southern Chile associated with Nothofagus species and with various introduced hosts (Flores et al. 1997). It has attributes of a pioneer species, being present in different plant stages from seedling to mature trees, and is considered a persistent species and a successful competitor. It is among the first species of ectomycorrhizal fungi that colonize newly formed plants growing in brown soils, dunes, volcanic ash or steep clearcuts. It is particularly recognized for its ability to tolerate water stress, and may be dominant in soils with low moisture content (Lo Buglio 1999).

\section{CONCLUSIONS}

Results of this study indicate that nursery inoculation with $R$. roseolus and $S$. luteus significantly improved ponderosa pine growth following outplanting in sites subjected to high water stress. These results also confirm that different ectomycorrhizal species behave differently after transplant, generating dissimilar plant growth that may not be detected at nursery stage. Inoculation with these edible mycorrhizal species should be considered for improving the quality of nursery-grown plants used for afforestation in Andean Patagonian grasslands, providing better tree growth and offering a non-timber product while stands are growing.

\section{ACKNOWLEDGEMENTS}

We thank Ing. F Ríos, Dra. L La Manna, Tec For. T Schinelli and Lic. L Contardi for contributions in the discussion of results and Dr. G Defossé for pre-submission critical review of the manuscript. This research was funded by FONCYT- PICT 2000-8674 and PIP-CONICET 80101000 .

\section{REFERENCIAS}

Agerer R, G Rambold. 2010. DEEMY-An Information System for Characterization and Determination of Ectomycorrhizae. München, Germany. Consulted 10 jun. 2010. Available in http://www.deemy.de

Amaranthus MP, N Malajczuk. 2001. The role of Rhizopogon mycorrhizae in drought tolerance of longleaf pine seedlings. In Cush JS ed. Forest for our future: Proceeding of the Third Longleaf Alliance Conference. Alexandria, LA, USA. Longleaf Alliance Report $\mathrm{N}^{\circ}$ 5. p. 77-82.

Barroetaveña C, M Rajchenberg. 2003. Las micorrizas y la producción de plántulas de Pinus ponderosa Dougl. et Laws. en la Patagonia Argentina. Bosque 24(1):17-33.

Barroetaveña C, M Rajchenberg, E Cázares. 2005. Mycorrhizal fungi in Pinus ponderosa introduced in Central Patagonia (Argentina). Nova Hedwigia 80: 453-464.

Barroetaveña C, MB Pildain, ME Salgado Salomon, JL Eberhart. 2010. Molecular identification of ectomycorrhizas associated with ponderosa pine seedlings in Patagonian nurseries (Argentina). Canadian Journal of Forest Research 40(10): 1940-1950.

Barroetaveña C, VN Bassani, M Rajchenberg. 2012. Inoculación micorrícica de Pinus ponderosa en la Patagonia Argentina: colonización de las raíces, descripción de morfotipos y crecimiento de las plántulas en vivero. Bosque 33(2): 163-169.

Bassani VN, C Barroetaveña, M Rajchenberg. 2013. Spores of ectomycorrhizal fungi as inoculants for Nothofagus pumilio and exotic conifer seedlings in Patagonia, Argentina: their activity and conservation. New Forests 44(4): 471-485. DOI: $10.1007 / \mathrm{s} 11056-012-9357-1$

Boa E. 2004. Wild edible fungi, a global overview of their use and importance to people. Non Wood Forest Products 17, FAO Technical papers. Rome, Italy. FAO. 147 p.

Castellano MA. 1996. Outplanting performance of mycorrhizal 
inoculated seedlings. In Mukerji KG ed. Concepts in Mycorrhizal Research. The Hague, Netherlands. Kluwer Academic Publishers. p. 223-301.

CFI- FUNDFAEP (Consejo Federal de Inversiones-Fundación para el desarrollo forestal, ambiental y del ecoturismo Patagónico, AR) 2009. Inventario de bosque implantado de la provincia de Neuquén. Buenos Aires, Argentina. Consejo Federal de Inversiones. $50 \mathrm{p}$.

Dahlberg AR, Finlay D. 1999. Suillus. In Cairney JWG, SM Chambers eds. Ectomycorrhizal fungi: key genera in profile. Berlin, Germany. Springer. p. 33-64.

Davel M, L Tejera, M Honorato, E Sepúlveda. 2006. Efecto del control de malezas sobre el prendimiento y crecimiento inicial de plantaciones de Pinus ponderosa en la Patagonia Argentina. Bosque 27(1): 16-22.

Di Rienzo JA, F Casanoves, MG Balzarini, L Gonzalez, M Tablada, CW Robledo. 2011. InfoStat Versión 2011. Grupo InfoStat, FCA, Universidad Nacional de Córdoba. Argentina.

Dunstan WA, B Dell, N Malajczuk. 1998. The diversity of ectomycorrhizal fungi associated with introduced Pinus spp. in the Southern Hemisphere, with particular reference to Western Australia. Mycorrhiza 8: 71-79.

Erland S, AFS Taylor. 1999. Resupinate ectomycorrhizal Fungi. In Cairney JWG, SM Chambers eds. Ectomycorrhizae fungi: key genera in profile. Berlin. Springer. p. 347-364.

Fernández MV, C Barroetaveña, VM Basanni, F Ríos. 2012. Rentabilidad del aprovechamiento del hongo comestible Suillus luteus para productores forestales y para familias rurales de la zona cordillerana de la provincia del Chubut, Argentina. Bosque 33(1): 43-52.

Fieldes M, KW Perrott. 1966. The nature of allophane in soils. Part 3. Rapid field and laboratory test for allophane. New Zealand Journal of Science 9(3): 623-629.

Flores R, R Godoy, G Palfner. 1997. Morfo-anatomía de la ectomicorriza Cenococcum geophilum Fr. en Nothofagus alessandrii Esp. Gayana Botanica 54(2): 157-162.

Godoy R, R Romero, R Carrillo. 1994. Estatus micotrófico de la flora vascular en bosques de coníferas del sur de Chile. Revista Chilena de Historia Natural 67: 209-220.

Guarnaschelli AB, AM Garau, JH Lemcoff. 2012. Water Stress and Afforestation: a contribution to ameliorate forest seedling performance during the establishment. In Mofizur Rahman I, H Hasegawa eds. Water Stress. Rijeka, Croatia. InTech. p. 73-112. DOI: 10.5772/32691
La Manna L, C Buduba, J Irisarri, J Ferrari, MV Cremona. 2011. Los nutrientes del suelo en la Región Andino Patagónica: una aproximación a la interpretación de datos analíticos. Patagonia Forestal 15(3):7-8.

Landis TD. 1985. Mineral nutrition as an index of seedling Quality. In Duryea ML ed. Proceedings of Workshop Evaluating seedling quality: principles, procedures, and predictive abilities of major tests. Corvallis, Oregon, USA. Forest Research Laboratory, Oregon State University. p. 29-48.

LoBuglio KF. 1999. Cenococcum. In Cairney JWG, SM Chambers eds. Ectomycorrhizal fungi: key genera in profile. Berlin, Germany. Springer. p. 287-309.

Martínez DB, C Barroetaveña, M Rajchenberg. 2007. Influencia del régimen de fertilización y del momento de inoculación en la micorrización de Pinus ponderosa en la etapa de vivero. Bosque 28(3): 226-233.

Parladé J, J Luque, J Pera, AM Rincón. 2004. Field performance of Pinus pinea and P. halepensis seedlings inoculated with Rhizopogon spp. and outplanted in formerly arable land. Annals of Forest Science 61: 507-514.

Peredo H, O Alonso, E Valenzuela. 1992. Inoculación micorrícica de Pinus ponderosa en el vivero forestal Junín de los Andes. Argentina. Ciencia e Investigación Forestal 6: 157167.

Querejeta JI, A Roldán, J Albaladejo, V Castillo. 1998. The role of mycorrhizae, site preparation, and organic amendment in the afforestation of a semi-arid mediterranean site with Pinus halepensis. Forest Science 44 (2): 203-211.

Richards JE. 1993. Chemical Characterization of Plant Tissue. In Carter Martin R ed. Soil Sampling and Methods of Analysis. Boca Raton, USA. Lewis Publishers. p. 115-139.

Rincón A, X Parladé, J Pera. 2007. Influence of the fertilization method in controlled ectomycorrhizal inoculation of two Mediterranean pines. Annals of Forest Science 64: 577583.

Smith SE, DJ Read. 1997. Mycorrhizal symbiosis, second edition. Cambridge. Academic Press. 605 p.

Steinfeld D, MP Amaranthus, E Cazares. 2003. Survival of ponderosa pine (Pinus ponderosa Dougl. ex Laws.) seedlings outplanted with Rhizopogon mycorrhizae inoculated with spores at the nursery. Journal of Arboriculture 29: 197-207.

Wada K. 1985. The distinctive properties of Andosols. In Stewart BA ed. Advances in Soil Science vol. 2. New York, USA. Springer Verlag. p. 173-229. 